\title{
The Nightingale Prize 2007
}

\author{
Jos A. E. Spaan
}

Received: 29 October 2008/ Accepted: 30 October 2008/Published online: 7 November 2008

(C) The Author(s) 2008. This article is published with open access at Springerlink.com

The yearly Nightingale Prize is given for the best scientific paper published in Medical and Biological Engineering and Computing (MBEC). The prize is named after the first Editor-in-Chief of MBEC, Alfred Nightingale, who died in1963 at the age of 40, just before the first issue was launched. The prize is an initiative of the Institute of Physics and Engineering in Medicine (IPEM) in collaboration with the International Federation of Medical and Biological Engineering (IFMBE). MBEC is the official journal of the Federation.

The time of selecting the winner of the Nightingale Prize is one of reflection on the fate of the journal. As reported in my editorial of last year [11] MBEC underwent large changes with respect to publisher and editor. This transition started halfway 2005 and a balance between submissions and publications was only restored well into 2006. The journal has since then steadily developed in a positive direction, with a growing increase in the supply of manuscripts. As a result, it becomes tougher to have a paper accepted in the journal and the current acceptance rate is approaching $25 \%$ on regular submissions. The number of citations to the papers published in MBEC is also rising and this trend is expected to continue in the coming years.

The selection process for the 2007 Nightingale Prize was slightly modified this year. Last year we first selected the most downloaded papers in 2006 and the top ten were ranked by members of the Editorial Board of MBEC. Technical problems prevented us from obtaining this

\section{J. A. E. Spaan $(\square)$}

Department of Biomedical Engineering and Physics,

AMC, University of Amsterdam, Amsterdam,

The Netherlands

e-mail: j.a.spaan@amc.uva.nl; MBEC@amc.uva.nl information this year and we used the earlier system by which the papers receiving the highest scores from the reviewers were selected for further judgment by the editors. The top ten papers entering the competition are in the reference list below and all deserve high recognition.

The paper selected for the 2007 Nightingale Prize is entitled 'An effective non-parametric method for globally clustering genes from expression profiles' by Hou et al. [6]. The authors are from two different institutions in Australia: the School of Engineering and Information Technology, Deakin University Burwood and The Walter and Eliza Hall Institute of Medical Research, Parkville. According to an expert reviewer: 'The key strength is the interesting novel algorithm for studying clustering genes and the paper outlines in welcome detail the mathematical underpinnings of this approach. The method was validated on both synthetic and real datasets'. We wholeheartedly congratulate the authors on their outstanding achievement.

A second paper on gene expression analysis by Maekawa et al. [8] received the following comments from an expert reviewer: 'A practical, clever solution to extract biological meaning from combined databases using a solid computational method that yields better results then existing methods'. It is good to see that MBEC is chosen to submit high-quality manuscripts on such timely topics as gene function and expression [12].

The editors like to see submissions describing novel approaches with a direct clinical application and in vivo validation and we are happy that such practice-oriented work was highly rated by the reviewers. Papers from this category on the shortlist relate to scoliosis, stroke rehabilitation and rehabilitation of patients with paralyzed upper extremities [1, 2, 9]. These three studies represent important contributions to advance clinical treatment of patients with serious chronic disabilities. 
Two other papers representing jewels in our journal dealt with development of models and techniques for future clinical application. One of these is on a model for deep tissue injury during prolonged wheelchair sitting [4] on which an expert reviewer commented: 'This is a good attempt to understand the contributions of many biomechanical factors for the risk for injury in the gluteus muscle pad during prolonged sitting'. Another example of such a jewel is an experimental study on the production of suspensions of microbubbles with a controlled diameter and tight size distribution, which is highly relevant for applications in ultrasound diagnosis and drug delivery [3]. This paper stimulated plans for a special issue on the production and use of microbubbles that is slated to appear in the spring of 2009.

MBEC traditionally receives a steady supply of manuscripts on bioelectrical phenomena and related instrumentation and signal processing. Papers in this area were also among the top ten and relate to electrical impedance tomography of the brain [5] and implantable instrumentation for wireless measurement of the electrocardiogram [10]. Although not primarily a journal for medical image analysis, MBEC is frequently chosen for submissions in this category. A top-ranked paper in this important field of research describes innovative work on the detection of fetal nuchal translucency thickness in ultrasound images [7], which is a discriminating marker in prenatal diagnosis.

The cross-section of topics covered by these ten excellent papers in MBEC nicely illustrates the broad nature of our journal, without restriction to specialized areas. We strive to be the international biomedical engineering journal of choice, which authors entrust with their original and innovative work and we want to especially encourage authors in the early stages of their career to submit their best research to MBEC.

Again, we express our gratitude to IPEM for maintaining the Alfred Nightingale Prize. We also extend our sincere appreciation to all authors who submitted manuscripts for consideration for publication in MBEC and provide our readers with important and interesting papers that span the entire spectrum of the field. Last but not least, we want to thank the many dedicated reviewers for their rigorous critiques and thoughtful recommendations that ultimately help to ensure the scientific quality of articles published in MBEC.

Jos A. E. Spaan

Editor-in-Chief
Open Access This article is distributed under the terms of the Creative Commons Attribution Noncommercial License which permits any noncommercial use, distribution, and reproduction in any medium, provided the original author(s) and source are credited.

\section{References}

1. Desroches G, Aubin CE, Sucato DJ, Rivard CH (2007) Simulation of an anterior spine instrumentation in adolescent idiopathic scoliosis using a flexible multi-body model. Med Biol Eng Comput 45(8):759-768. doi:10.1007/s11517-007-0214-x

2. Eng K, Siekierka E, Pyk P, Chevrier E, Hauser Y, Cameirao M, Holper L, Hagni K, Zimmerli L, Duff A, Schuster C, Bassetti C, Verschure P, Kiper D (2007) Interactive visuo-motor therapy system for stroke rehabilitation. Med Biol Eng Comput 45(9):901-907. doi:10.1007/s11517-007-0239-1

3. Farook U, Stride E, Edirisinghe MJ, Moaleji R (2007) Microbubbling by co-axial electrohydrodynamic atomization. Med Biol Eng Comput 45(8):781-789. doi:10.1007/s11517-007-0210-1

4. Gefen A (2007) Risk factors for a pressure-related deep tissue injury: a theoretical model. Med Biol Eng Comput 45(6):563573. doi:10.1007/s11517-007-0187-9

5. Gilad O, Horesh L, Holder DS (2007) Design of electrodes and current limits for low frequency electrical impedance tomography of the brain. Med Biol Eng Comput 45(7):621-633. doi: 10.1007/s11517-007-0209-7

6. Hou J, Shi W, Li G, Zhou W (2007) An effective non-parametric method for globally clustering genes from expression profiles. Med Biol Eng Comput 45(12):1175-1185. doi:10.1007/s11517007-0271-1

7. Lee YB, Kim MJ, Kim MH (2007) Robust border enhancement and detection for measurement of fetal nuchal translucency in ultrasound images. Med Biol Eng Comput 45(11):1143-1152. doi:10.1007/s11517-007-0225-7

8. Maekawa S, Matsumoto A, Takenaka Y, Matsuda H (2007) Tissue-specific functions based on information content of gene ontology using cap analysis gene expression. Med Biol Eng Comput 45(11):1029-1036. doi:10.1007/s11517-007-0274-y

9. Nef T, Mihelj M, Riener R (2007) ARMin: a robot for patientcooperative arm therapy. Med Biol Eng Comput 45(9):887-900. doi:10.1007/s11517-007-0226-6

10. Riistama J, Vaisanen J, Heinisuo S, Harjunpaa H, Arra S, Kokko K, Mantyla M, Kaihilahti J, Heino P, Kellomaki M, Vainio O, Vanhala J, Lekkala J, Hyttinen J (2007) Wireless and inductively powered implant for measuring electrocardiogram. Med Biol Eng Comput 45(12):1163-1174. doi:10.1007/s11517-007-0264-0

11. Spaan JA (2007) The Nightingale Prize for the best scientific paper published in MBEC 2006. Med Biol Eng Comput 45(12):1161-1162. doi:10.1007/s11517-007-0287-6

12. Wang Z, Wei GH, Liu DP, Liang CC (2007) Unravelling the world of cis-regulatory elements. Med Biol Eng Comput 45(8):709-718. doi:10.1007/s11517-007-0195-9 